\title{
PENGEMBANGAN MODEL TEACHERPRENEUR PADA SEKOLAH MENENGAH KEJURUAN
}

\author{
Wisnu Rachmad Prihadi \\ Pendidikan Teknologi Kejuruan konsentrasi Vokasi Sipil dan Perencanaan PPs UNY \\ wisnurachmadprihadi@gmail.com \\ Herminarto Sofyan \\ Fakultas Teknik Universitas Negeri Yogyakarta \\ hermin@uny.ac.id
}

\begin{abstract}
Abstrak
Penelitian ini bertujuan: (1) mengungkapkan pengembangan profesionalitas pendidik yang selama ini diterapkan; (2) menemukan model pengembangan teacherpreneur; dan (3) menentukan keefektifan internal model teacherpreneur di SMK Bidang Keahlian Teknologi dan Rekayasa. Penelitian ini menggunakan metode research and development yang terdiri dari tiga langkah: studi pendahuluan, pengembangan model, dan uji coba internal. Penelitian dilakukan di SMK negeri dan swasta di kota Yogyakarta. Pengumpulan data penelitian menggunakan wawancara mendalam dan observasi. Hasil penelitian menunjukkan bahwa: (1) pengembangan profesionalitas pendidik pada guru SMK yang diteliti sebagian besar berasal dari pemerintah, dan dari sekolah. Program pemerintah terdiri dari $M G M P$, OJT, sosialisasi kurikulum, ujian kompetensi, dan diklat assessor, sedangkan program pengembangan pendidik di sekolah bergantung pada kebijakan dan strategi dari masing-masing kepala sekolah; (2) Model teacherpreneur yang dikembangkan tersusun atas komponen kompetensi, kreatifitas, dan efektivitas; (3) Keefektifan model hasil uji internal yang dilakukan dapat disimpulkan bahwa ahli setuju dengan kategori: (a) komponen model telah lengkap (92,83\%); (b) struktur komponen model telah jelas (91,65\%); (c) hubungan antar komponen model telah jelas (95,83\%); (d) keterbacaan model telah baik (95,83\%); (e) model telah layak (95,83\%); dan (f) model efektif jika diimplementasikan $(87,5 \%)$.
\end{abstract}

Kata kunci: pengembangan, profesionalitas, pendidik, teacherpreneur

\section{DEVELOPING A MODEL OF TEACHERPRENEUR IN VOCATIONAL HIGH SCHOOLS}

\begin{abstract}
This research aimed to: (1) reveal the teacher's professional development model currently applied; (2) generate a teacherpreneur development model; and (3) determine the internal effectiveness of teacherpreneur development model in the vocational high schools (SMK) having the study program of technology and engineering expertise. This research employed the research and development method which consisted of three steps: preliminary study, model development, and internal try-out of the model. It was conducted at SMK Negeri 2 Yogyakarta, SMK Muhammadiyah 3 Yogyakarta, SMK Negeri 3 Yogyakarta, SMK Perindustrian, SMK PIRI 1 Yogyakarta, and SMK Taman Siswa Jetis Yogyakarta. The research data were collected through in-depth interviews and observation. The results are as follows: (1) the professional development of the teachers were mostly programmed by the government and school. The government program consisted of the association of the subject teachers (MGMP), OJT, curriculum socialization, competence examination, and assessor training, while the school program depended on the policy and strategies of each principal; (2) the teacherpreneur developed consisted of the componenets of competency, creativity, and effectiveness; (3) the result of the internal try-out involving the authority in the City Education Office, the experts of vocational education, and the SMK administrators concluded that: (a) 92.83\% of experts agreed that the components of the model were sufficient, (b) $91.65 \%$ of experts agreed that the structure of the components of the model was understood, (c) $95.83 \%$ of the experts agreed that the relationship between the components was clear, (d) $95.83 \%$ of the experts agreed that the model had good readability, (e) $95.83 \%$ of the experts agreed that the model was appropriate, and $(f)$ 87.5\% agreed that the model would be effective for implementation.
\end{abstract}

Keywords: development, professionalism, educator, teacherpreneur 


\section{PENDAHULUAN}

Guru merupakan suatu profesi sebagaimana halnya dengan profesi lain yang menuntut keahlian tertentu, menuntut tanggung jawab, memiliki pemahaman terhadap keilmuan dan mengetahuai cara penyelesaian problematika yang dihadapi sesuai dengan bidang keilmuan serta kesetiaannya dalam menjalankan profesi. Profesi guru dituntut memiliki keahlian yang memadai dalam membimbing, mengajar, dan mendidik peserta didik. Hal ini telah dijelaskan secara tegas dalam UndangUndang Guru dan Dosen (UU No. 14 Tahun 2005) yang menyatakan bahwa guru profesional adalah guru yang mampu berperan untuk mendidik, mengajar, membimbing, mengarahkan, melatih, menilai dan mengevaluasi peserta didik dengan menggunakan keahlian sesuai standar yang berlaku.

Guru merupakan komponen yang paling berpengaruh terhadap terciptanya proses dan hasil pendidikan yang berkualitas. Perbaikan apapun yang dilakukan dalam sistem pendidikan guna meningkatkan kualitas pendidikan tidak akan memberi kemajuan tanpa didukung peningkatan kualitas dan profesionalitas guru. Guru merupakan aplikator yang terlibat langsung dalam pembentukan sumber daya manusia (SDM) pada wadah sekolah. Proses pendidikan dikatakan berhasil apabila mampu melibatkan sebagian besar peserta didik secara aktif, baik fisik, mental, maupun sosial dalam proses pembelajaran dan juga gairah, semangat dan percaya diri dalam belajar. Dari sisi hasil pendidikan dikatakan berhasil apabila pembelajaran yang diberikan mampu mengubah perilaku sebagian besar peserta didik ke arah penguasaan kompetensi yang lebih baik dengan ditunjukan dari aspek pengetahuan, keterampilan, sikap, dan nilai yang dimiliki.

Kualitas guru-guru di Indonesia belum menunjukkan hasil yang maksimal hal ini dapat dilihat dari hasil Uji Kompetensi Awal (UKA) bagi calon peserta sertifikasi dan Uji Kompetensi Guru (UKG) bagi guru yang sudah bersertifikasi yang dilaksanakan pada tahun 2012 terlihat bahwa nilai rata-rata komulatif kurang dari 50 dari apa yang disyaratkan pemerintah. Data hasil ujian UKA dapat dijelaskan bahwa perolehan nilai ratarata guru TK sebesar 58,87, guru SD sebesar 36,86 , guru SMP sebesar 46,15, guru SMA sebesar 51,35, dan guru SMK sebesar 50,02 dari total peserta UKA 281.016 orang (sumber: Dikmen, 2012). Hasil UKA dan UKG menjadi masukkan bagi guru, sekolah, Lembaga Penjamin Mutu Pendidikan (LPMP), dinas pendidikan dan lembaga pendidikan tenaga kependidikan (LPTK) untuk meningkatkan pembinaan dan pengembangan profesionalisme guru dan calon guru. Hal ini dikarenakan peran guru yang begitu besar dan termasuk komponen utama dalam sistem pendidikan yang tidak dapat digantikan, terlebih di sekolah menengah kejuruan.

Guru sekolah menengah kejuruan yang disingkat guru SMK adalah guru yang mengajar pada satuan pendidikan formal yang menyelenggarakan pendidikan kejuruan. Guru kejuruan pada program produktif memiliki karakteristik yang kompleks dan persyaratan yang profesional di antaranya: memiliki keahlian praktis yang memadai pada semua bidang studi (mata pelajaran produktif), mampu menyelenggarakan pembelajaran (diklat) yang relevan dengan kompetensi yang dibutuhkan oleh dunia kerja, dan mampu merancang pembelajaran di sekolah dan di dunia usaha atau industri (Sardi Salim, 2009). Guru kejuruan dituntut untuk selalu meng-update dan mengupgrade keilmuan yang dimiliki terhadap perubahan yang terjadi pada dunia industri untuk dapat disesuaikan dengan kondisi di sekolah.

Berangkat dari kenyataan tersebut, upaya peningkatan kualitas guru SMK terus dilakukan dengan cara berbagai program peningkatan profesionalitas guru. Peningkatan profesionalitas guru sebenarnya merupakan tanggung jawab guru secara individual sejalan dengan perubahan pada tempat kerja, perkembangan ilmu pengetahuan, teknologi dan peserta didik. Guru secara individu dapat meningkatkan kompetensinya sebagai agen pembelajaran melalui pengalaman-pengalaman keseharian di kelas atau melalui komunikasi dengan rekan sejawat dalam merencanakan, melaksanakan dan mengevaluasi pembelajaran yang telah dilakukan. Namun, kenyataan yang ada tidak menunjukkan hal demikian. Berdasarkan hasil penelitian yang dilakukan oleh Tri Jalmo (2008) diterangkan bahwa tidak ada perbedaan yang signifikan antara guru yang berpengalaman mengajar kurang dari lima tahun dengan yang mengajar lebih dari lima tahun dalam mengembangkan tes 
hasil belajar, dan kegiatan pembelajaran. Hal ini menggambarkan pengembangan profesional guru secara individu belum terlaksana dengan baik.

Pemerintah ikut terlibat dan mengatur upaya peningkatan profesionalitas guru. Hal ini tercantumkan dalam Undang-Undang Sisdiknas Dosen (UU No. 20 Tahun 2003 pasal 40 ayat 1c) disebutkan bahwa "setiap pendidik dan tenaga kependidikan mempunyai hak memperoleh pembinaan karir sesuai dengan tuntutan pengembangan kualitas". Di antara upaya pemerintah melalui berbagai program kegiatan pelatihan, workshop, membentuk asosiasi guru mata pelajaran, memberdayakan program Musyawarah Guru Mata Pelajaran (MGMP) serta program kegiatan lainnya. Namun, hasil dari pelaksanaan program tersebut masih belum optimal bahkan banyak pelatihan yang dapat dinilai gagal dalam meningkatkan kinerja guru di kelas. Pernyataan di atas diperkuat dari hasil penelitian Tri Jalmo (2008) bahwa kompetensi pedagogi, khususnya melaksanakan penilaiaan ternyata antara guru yang pernah mengikuti pelatihan dengan guru yang tidak atau belum pernah mengikuti pelatihan tidak berbeda secara signifikan. Hasil tersebut menjadi bukti belum berhasilnya pelatihan yang diselenggarakan, atau terdapat kesalahan dalam merancang atau pelaksanaan pelatihan.

Peningkatan profesionalitas guru berupa kegiatan pendidikan dan pelatihan (diklat) seharusnya memiliki dampak terhadap peningkatan kualitas guru dalam pembelajaran, peningkatan keilmuan, produktivitas guru dalam keilmuan dan lebih jauh lagi harus memiliki dampak pada peningkatan kualitas dan hasil belajar siswa. Ketidakberhasilan dalam pengembangan profesionalitas guru merupakan salah satu isu strategis yang terus berkembang terkait dengan konteks, serta model dalam pelaksanaan diklat. Selain itu permasalahan umumnya yang sering muncul adalah materi yang diberikan tidak sesuai dengan kebutuhan di lapangan, metode yang monoton, keterkaitan antara materi yang telah lalu tidak ada, serta keterbatasan waktu pelaksanaan diklat.

Penerapan model pelatihan sebagai bagian dari keterlaksanaan proses belajar mengajar diklat, berkaitan erat dengan kualitas pengembangan model pembelajaran di diklat. Artinya, jika suatu desain model pelatihan dikembangkan secara baik dan melalui tahapan yang benar, berpeluang besar dapat dipergunakan secara maksimal. Namun, hal itu belum menjamin sepenuhnya, sebab banyak model pelatihan yang dikembangkan dengan baik tidak jarang kurang berhasil dalam pelaksanaan. Saat ini, model pelatihan yang digunakan dalam pelaksanaan diklat bagi guru kejuruan adalah model lima langkah dengan sistem paket dengan menentukan kompetensi apa yang diperlukan, jadwal, metode, atau terkadang pelatihan akan diberikan apabila terjadi perubahan kurikulum.

Tantangan guru sekarang ini dan di masa depan sangatlah berat. Hal ini akibat persaingan antarnegara yang semakin ketat termasuk persaingan dalam hal sumber daya manusia (SDM). Selain itu, perkembangan teknologi yang begitu pesat dan penemuan yang begitu cepat mengakibatkan ilmu pengetahuan menjadikan mudah didapat dan terdapat ilmu-ilmu yang sifatnya singkat. Fasilitas dan media sumber belajar telah banyak tersedia dan beberapa telah dimiliki di sekolah-sekolah. Guru yang merupakan agen perubahan di mana fungsi guru tidak hanya menjadi pendidik, akan tetapi juga sebagai fasilitator, motivator, inovator. Hal ini menuntut guru untuk terus mengembangkan profesionalitas agar guru dapat menjalankan tugasnya sebagai guru dengan mengikuti ritme perubahan yang terjadi baik dari teknologi, metode serta peserta didik.

Salah satu contoh paradigma guru zaman sekarang yaitu guru dituntut untuk memahami penggunaan teknologi baik teknologi yang digunakan untuk kegiatan pembelajaran, maupun teknologi yang terdapat pada bidang keahliannya, serta penggunaan metode pembelajaran yang beranekaragam. Pendekatan yang digunakan guru dalam pembelajaran juga harus berubah. Guru lebih berperan sebagai fasilitator pembelajaran dibandingkan dengan sumber pembelajaran. Surya Dharma (2012) menjelaskan terjadi perubahan paradigma dalam mengajar yang dilakukan guruguru zaman dulu dengan cara mengajar guru zaman sekarang. Hal ini disebabkan terjadi perkembangan ilmu pengetahuan dan teknologi yang berkembang sangat pesat. Perkembangan teknologi tersebut ikut mempengaruhi perkembangan siswa maupun dunia pendidikan. Contohnya, teknologi telekomunikasi atau handphone sekarang ini yang telah sangat 
canggih menjadikan handphone dapat berfungsi mengakses internet sehingga mempermudah mendapatkan informasi dengan cepat. Akibat perkembangan teknologi tersebut cara belajar anak juga ikut berubah.

Tantangan profesionalitas guru di masa sekarang ini tidak sebatas kemampuan guru dalam hal kompetensi saja, akan tetapi guru dalam proses peningkatan mutu pendidikan dituntut lebih kreatif dan efektif. Untuk memperoleh sikap tersebut dapat mengadopsi sikap positif yang dimiliki dari seorang pengusaha (entrepreneur), saat seorang pengusaha wajib memiliki sikap kompetensi yang baik dalam bidangnya, memiliki sikap kreatif dalam mengembangkan produk, kemasan dan penyampaian produk, serta aktif dalam berbagai kegiatan pengembangan, dan efektif dalam pemasaran produk. Sikap ini bukan menjadikan guru untuk beralih profesi dari seorang guru menjadi pengusaha, akan tetapi merupakan pengadopsian sikap yang dimiliki seorang entrepreneur. Dijelaskan oleh Novan (2012) teacherpreneur tidak menjadikan guru sebagai pengusaha, tetapi menjadikan guru berjiwa kewirausahaan. Guru harus memiliki kompetensi yang baik, sikap kreatif dalam menyelenggarakan pembelajaran, dan efektif dalam menerapkan metode penyampaian pembelajaran sehingga peserta lebih cepat dalam memahami pembelajaran yang diberikan dan tidak membosankan. Terlebih lagi hal itu terjadi pada guru kejuruan yang memiliki banyak potensi dan peran begitu besar. Guru kejuruan dituntut menyiapkan lulusan agar menjadi SDM yang siap mengaplikasikan bidang keilmuan, dan memiliki pola pikir yang terus berkembang sebagaimana yang tertuang dalam tujuan pendidikan kejuruan.

Keadaan di lapangan masih jauh dari yang diharapkan, hal ini dikarenakan banyak faktor yang salah satunya disebabkan dari keadaan guru di sekolah kejuruan belum secara penuh membentuk dan mengarahkan peserta didik secara totalitas dan integrasi antara teori dan praktek masih dirasa belum memiliki keterkaitan yang baik. Menimbang permasalahan tersebut diperlukan upaya peningkatan kompetensi guru khususnya guru kejuruan melalui kegiatan pelatihan dengan konsep teacherpreneurship. Sejatinya seorang guru juga merupakan seorang pengusaha yang dapat mengembangkan dalam bidang keilmuan yang dimiliki seperti guru membuat modul, membuat buku pelajaran, atau guru merancang produk yang memiliki nilai ekonomis dan kebermanfaatan berdasarkan pengembangan keilmuan yang dimiliki.

Menyadari kondisi, peran, dan fungsi dari program pengembangan guru pada sekolah menengah kejuruan yang selama ini belum mampu secara efektif memperbaiki kualitas pembelajaran yang dilakukan oleh peserta, maka perlu dikembangkan model pengembangan profesionalisme guru yang berangkat dari berbagai kelemahan dan keunggulan program kegiatan pengembangan guru yang telah berjalan selama ini. Program yang dikembangkan harus dapat mengubah mindset guru dengan meningkatkan kreatifitas dan efektivitas guru dalam melaksanakan tugas sebagai seorang guru dalam hal kegiatan pembelajaran.

Model pelatihan guru di pendidikan kejuruan berbeda dengan pelatihan pada guru umum. Model pelatihan pada guru kejuruan dalam penerapannya harus memiliki dan mencakup dua ciri, yaitu pelatihan berbasis kompetensi (competencies based training) dan pelatihan berbasis produksi (production based training) dengan memperhatikan hasil akhir suatu produk. Pelatihan berbasis kompetensi adalah proses pelatihan yang perencanaan, pelaksanaan, dan penilaiannya mengacu pada penguasaan kompetensi yang telah disepakati antara institusi asal peserta dengan institusi pasangan. Sedangkan pelatihan berbasis produksi adalah pelatihan keterampilan yang dirancang dan dilaksanakan berdasarkan prosedur dan standar kerja sesungguhnya (real job), untuk menghasilkan barang atau jasa sesuai tuntutan pasar atau konsumen.

Berdasarkan permasalahan dan pertimbangan pemikiran di atas, maka diperlukan penelitian pengembangan model bagi peningkatan profesionalitas guru sekolah menengah kejuruan yang kemudian diberi nama model teacherpreneur. Pengembangan model teacherpreneur merupakan pengadopsian sikap positif yang dimiliki entrepreneur ke dalam profesi seorang guru kejuruan, yang mana guru kejuruan memiliki banyak potensi selain dalam bidang pendidikan juga dalam penyiapan SDM yang berkualitas. Pengembangan model ini nantinya terdiri dari rancangan model konseptual dalam pelatihan bagi guruguru SMK dengan lebih menekankan pada 
unsur kreatifitas dan keefektifan dalam bidang kejuruan.

\section{METODE PENELITIAN}

Hasil akhir penelitian ini adalah ditemukannya model pengembangan pendidik di SMK yang diberi nama model teacherpreneur. Penelitian ini menggunakan metode Penelitian dan Pengembangan (Research and Development/ $R \& D$ ). Prosedur $\mathrm{R} \& \mathrm{D}$ yang mengacu pada Borg \& Gall (1989). Dari 10 tahap pengembangan yang dikemukakan oleh Borg \& Gall, peneliti hanya menyuplik tiga tahapan yaitu: studi pendahuluan, pengembangan model, dan pengujian internal model

Sebelum dikembangkan model teacherpreneur di SMK, dilakukan need assessment yang bertujuan untuk mengetahui kebutuhan atau gambaran awal mengenai pengembangan pendidik yang telah dilakukan di SMK. Penelitian yang dilakukan menggunakan pendekatan kualitatif dengan pendekatan RnD.

Penelitian dan pengembangan ini dilakukan melalui tiga tahap. Tahap pertama merupakan penelitian yang dimaksudkan untuk memperoleh informasi awal mengenai pengembangan profesionalitas guru yang telah dilakukan selama ini. Tahap kedua merupakan tahap perencanaan atau desain awal konsep pengembangan teacherpreneur. Tahap ketiga merupakan tahap pengembangan model. Pada tahap ini dilakukan validasi model dan uji keefektifan internal. Validasi model dilakukan oleh ahli manajemen pendidikan, ahli pendidikan kejuruan, dan birokrat yang berasal dari Dinas Pendidikan kota Yogyakarta. Uji keefektifan internal dilakukan di setiap sekolah dengan cara teknik Delphi. Melalui teknik Delphi didapatkan kesepakatan panelis terhadap model yang akan dirancang sesuai dengan kelemahan-kelemahan yang terdapat pada pengembangan yang telah berjalan selama ini.

Penelitian ini dilaksanakan pada bulan November 2014 hingga Februari 2015. November - Desember 2014 digunakan untuk menganalisis kebutuhan, Desember 2014 Januari 2015 mengembangkan model pola sumber-sumber dana sekolah, sedangkan Januari - Februari 2015 digunakan untuk uji coba/validasi model dan uji keefektifan internal.
Lokasi penelitian yang dipilih adalah enam SMK Bidang Keahlian Kelompok Teknologi dan Rekayasa di Kota Yogyakarta yang terdiri dari: SMK Negeri 2 Yogyakarta, SMK Negeri 3 Yogyakarta, SMK Muhammadiyah 3 Yogyakarta, SMK PIRI 1 Yogykarta, SMK Taman Siswa Jetis, dan SMK Perindustrian Yogyakarta. Keenam SMK tersebut merupakan perwakilan dari SMK Kluster dan SMK Non-Kluster yang berada di Kota Yogyakarta.

Responden penelitian terdiri dari kepala sekolah, wakil kepala sekolah bidang kurikulum, QMR (Quality Management Representative), ketua jurusan, guru produktif yang berjumlah 3 orang di setiap sekolah.

Teknik pengumpulan data yang digunakan dalam penelitian ini adalah: (1) observasi langsung di lokasi penelitian dengan dibantu alat perekam gambar dan suara, (2) wawancara mendalam kepada semua responden yang telah ditentukan, dan (3) melihat dokumen yang ada di sekolah yang meliputi: RAPBS, program kerja wakil kepala sekolah bidang kurikulum, matriks program peningkatan guru pendidikan menengah Dinas Pendidikan, serta data-data lain yang dibutuhkan dan mendukung dalam penelitian berkaitan dengan pengembangan pendidik yang selama ini berlangsung. Validasi instrumen dan model dilakukan secara terbatas pada tiga orang yang memiliki kapasitas kepakaran mengenai pengembangan pendidik, managemen pendidik/ guru.

Data yang didapat dari hasil wawancara, pengamatan, dan dokumentasi dianalisis dan diinterpretasi untuk memenuhi tuntutan tujuan penelitian dan informasi lainnya. Agar penyajian data lebih bermakna dan mudah dipahami maka langkah analisis data yang digunakan dalam penelitian ini menggunakan analysis interactive model dari Miles dan Huberman (1994, p. 23) yang membagi kegiatan analisis menjadi beberapa bagian, yaitu: pengumpulan data, reduksi data, penyajian data, dan penarikan kesimpulan.

\section{HASIL PENELITIAN DAN PEMBAHASAN}

Berdasarkan wawancara, observasi, dan dokumentasi yang dilakukan di enam SMK dapat digambarkan pengembangan pendidik yang berlangsung pada SMK negeri. 


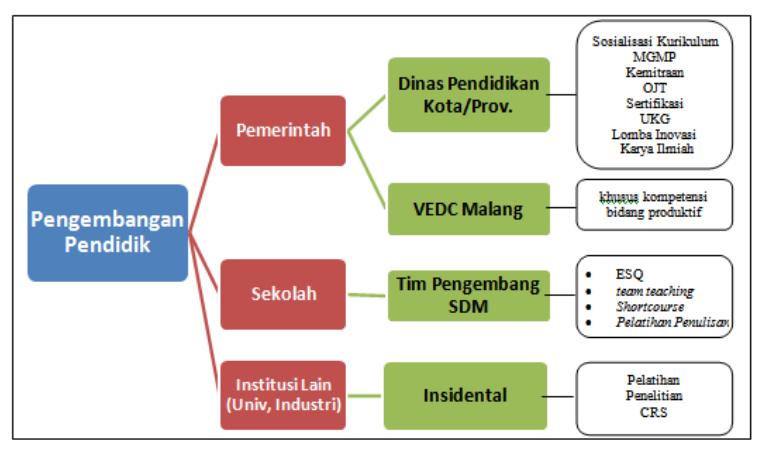

Gambar 1. Skema Pengembangan Pendidik yang berlangusng pada SMK Negeri di Kota Yogyakarta

Pada Gambar 1 dapat dijelaskan bahwa pengembangan pendidik pada SMK negeri di kota Yogyakarta terdiri dari program pemerintah, program sekolah dan Institusi lain. Program pemerintah secara umum berlaku pada seluruh sekolah negeri ataupun swasta. Program sekolah bergantung arah kebijakan dari masing-masing kepala sekolah dan ketua jurusan dalam menyelenggarakan pengembangan pendidik, dapat berupa pelatihan-pelatihan yang ditujukan meningkatkan kualitas dari guru-guru, team teaching, shortcourse (kursus singkat), dan program lainnya. Program pengembangan pendidik yang berasal dari institusi lain dilakukan oleh perguruan tinggi, industri sebagai bentuk pengabdian, penelitian atau kepedulian kepada pendidikan. Kegiatan pengembangan yang dilakukan oleh institusi lain adalah pelatihan dari industri kepada guru-guru sekolah yang harapannya dihasilkan lulusan SMK yang telah siap bekerja sesuai standar yang diinginkan di industri.

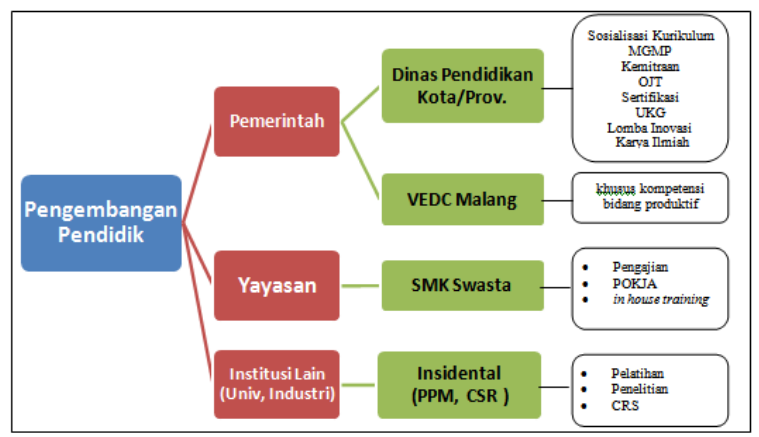

Gambar 2. Skema Pengembangan Pendidik pada SMK swasta di Kota Yogyakarta

Skema pengembangan pendidik yang berlangsung pada SMK swasta hanya terdapat perbedaan dalam hal peran yayasan. Artinya, segala kegiatan yang dilak-sanakan di sekolah harus benar-benar disetujui oleh yayasan.

Pada Gambar 2 dapat dijelaskan bahwa terdapat peran yayasan dalam mengembangkan SDM yang ada termasuk dalam hal pendidik. Hal ini dikarenakan peran yayasan yang membawa idelogi dari masing-masing yayasan, dan dalam pelaksanaan disesuaikan dengan anggaran yang ada.

Berdasarkan hasil penelitian, ditemukan permasalahan dan kelemahan yang sering terjadi terkait pengembangan pendidik yang terjadi pada setiap sekolah, sehingga hasil yang diperoleh dari pelaksanaan pengembangan pendidik kurang maksimal, permasalahan tersebut yaitu: (1) kendala yang sering dihadapi guru dalam mengikuti kegiatan pengembangan adalah dalam hal pembagian waktu antara jam mengajar dengan jam kegiatan seperti kegiatan MGMP, atau dikarenakan kelelahan dalam mengajar menjadi tidak mengikuti kegiatan pengembangan; (2) belum terdapat evaluasi kemampuan/kompetensi guru terkait setelah pelaksanaan kegiatan pengembangan, sehingga gambaran hasil yang ingin dituju belum diketahui; (3) pada sekolah swasta faktor anggaran merupakan salah satu faktor yang perlu ditimbangkan dalam melangsungkan kegiatan pengembangan yang diadakan mandiri oleh sekolah. Hal ini dikarenakan sumber pendanaan sekolah dalam melangsungkan operasional sekolah berasal dari siswa; (4) perbedaan iklim kerja dan lingkungan antara sekolah swasta dan sekolah negeri; (5) efektivitas pembinaan terhadap kemampuan profesional guru menengah kejuruan yang diterapkan selama ini masih lemah, kelemahan dari aspek perencanaan, pelaksanaan, dan pengawasan. Hal ini dapat dilihat dari kualitas dan kompetensi hasil akhir dari pelaksanaan program pengembangan yang kurang maksimal. Hal ini dapat dilihat dari perolehan hasil ujian kompetensi guru (UKG) yang telah diikuti, yang masih terdapat guru yang memiliki nilai kurang dari apa yang disyaratkan. Selain itu berdasarkan produktivitas dan prestasi yang dihasilkan guru belum sepenuhnya memaksimalkan kompetensi dan pengembangan keilmuan, dapat dilihat dari produktivitas karya-karya yang dihasilka;.(6) Pembinaan dalam bentuk diklat dalam jabatan bagi guru kejuruan selama ini dirasa kurang memberikan hasil optimal, khususnya dalam 
mengembangkan kemampuan dan keahlian aktual yang sesuai dengan perkembangan industri/ dunia usaha. (7) Kurangnya perhatian dari pengelola/pimpinan/kepala sekolah dalam hal pelaksanaan pengembangan bagi pendidik. Pengembangan pendidik belum dirasa suatu hal yang penting.

Melihat kondisi yang terjadi tersebut diperlukan partisipasi semua pihak (stakeholder) yang terlibat dalam pengembangan pendidik. Dari beberapa kelemahan terdapat keunggulan yang perlu dipertahankan dan ditingkatkan yaitu: (1) Telah terdapat banyak program pengembangan pendidik yang diadakan oleh pemerintah maupun sekolah yang telah terumuskan di dalam RKAS selama satu tahun. Artinya, pengembangan pendidik yang dilakukan secara rutinitas telah dirumuskan dan telah ada standar minimal yang harus diikuti sebagai seorang pendidik. Hal itu tertuang dalam matrik program kerja Dinas Pendidikan terdapat program MGMP, sertifikasi keahlian, UKG, sebagai syarat seorang guru profesional. (2) sebagian besar sekolah telah memiliki fasilitas dan sarana belajar yang memadai dan telah lengkap, artinya sarana atau fasilitas bukanlah menjadi kendala hal pelaksanaan pembelajaran dikarenakan sekolah telah diberi bantuan operasional sekolah (BOS) untuk pengadaan alat dan media sarana belajar; (3) banyak teknologi informasi dan komunikasi (TIK) di zaman sekarang ini yang dapat dimanfaatkan untuk membantu mempermudah dalam pelaksanaan kegiatan pembelajaran, sehingga guru dapat belajar secara mandiri melalui video, sumber bacaan lain, jurnal, atau sejenisnya. Selain itu, dengan adanya TIK membantu guru dalam menjelaskan kegiatan pembelajaran kepada siswa, melalui media atu alat bantu yang didapat dari internet, sehingga siswa menjadi lebih mudah memahami; (4) kualifikasi dari guru-guru yang ada di SMK sebagian besar telah memenuhi dari apa yang disyaratkan yaitu minimal S1/DIV, artinya guru telah dibekali dengan kompetensi yang dimiliki; (5) manajemen berbasis sekolah yang telah diterapkan di masingmasing SMK perlu dipertahankan, sehingga manajemen sekolah dapat dengan leluasa membina SDM-nya sesuai visi dan misi yang ditetapkan oleh sekolah. Keenam keterlibatan dan kedekatan dengan LPTK dan perguruan tinggi memudahkan pengembangan pendidik dalam program pembinaan guru-guru SMK di
Kota Yogyakarta; (7) Menjalin kerjasama dengan dunia industri serta organisasi profesi. Beberapa SMK telah menjalin kerja sama dengan pihak industry, sebagai contoh SMK PIRI Yogyakarta telah bekerja sama dengan Perusahaan Yamaha.

Berdasarkan hasil analisis program pengembangan pendidik yang selama ini berlangsung maka dikembangkan model teacherpreneur. Model yang dikembangkan ini pada dasarnya merekonstruksi aktivitas pelatihan (training) dan non-pelatihan (non-training) untuk menghasilkan dampak pada peningkatan kualitas praktik pembelajaran yang dilakukan oleh guru dan produktivitas yang bisa diperoleh dari profesi seorang guru. Aktivitas pelatihan dilakukan untuk memperluas dan meningkatkan pengetahuan, keterampilan, dan sikap guru dalam melakukan tugas dan tanggung jawab dalam menjalankan profesi seorang guru dan perkembangan apa saja yang dapat dikembangkan. Selain itu, aktivitas nonpelatihan seperti pemantapan dukungan iklim dan kondisi kerja di sekolah, dinamika kelompok, dan persepsi guru dimaksudkan untuk menciptakan konteks yang lebih kondusif guna meningkatkan efektivitas pelatihan. Selanjutnya, konstruksi model teacher-preneur terdiri dari tiga komponen yang bersifat saling berkaitan yaitu komponen kompetensi, komponen kreativitas yang harus dimiliki seorang guru, dan komponen efektivitas. Uraian secara lengkap ketiga komponen dapat dirinci pada model konseptual sebagai berikut.

Model teacherpreneur terdiri dari komponen kompetensi, kreativitas dan efektivitas. Seluruh komponen tersebut tidak dapat dipisahkan antara satu dan lainnya. Model teacherprenur yang termasuk ke dalam peningkatan keprofesionalan guru. Untuk menghadapi tantangan abad 21 dan bersaing dengan negara lain tidaklah cukup dengan peningkatan keprofesionalan guru dengan cara meningkatkan komponen kompetensi saja, yang selama ini sering di latihkan. Diperlukan akan inovasi dan integrasi antara beberapa komponen yaitu aspek kreativitas dan keefektifan dari seorang guru dalam penggunaan berbagai macam sumber daya dalam kegiatan belajar mengajar.

Seorang guru diwajibkan memiliki kompetensi yang baik dalam melaksanakan tugas sebagai seorang guru yang terdiri dari kompetensi pedagogik berkaitan dengan cara 
atau kemampuan guru dalam mengajar, kompetensi sosial berkaitan dengan hubungan guru terhadap siswa dan orangtua siswa/wali serta masyarakat, kompetensi kepribadian berkaitan dengan tuntutan pribadi yang harus dimiliki seorang guru, dan kompetensi profesional berkaitan dengan penguasaan guru terhadap materi yang diajarkan.

Komponen kreativitas guru merupakan kemampuan menyelesaikan pembelajaran dengan baik yang ditunjukkan oleh peningkatan hasil belajar. Artinya guru menggunakan/ mendayagunakan sumber daya yang ada dalam kegiatan pembelajaran untuk meningkatkan kemampuan baik itu dengan mengubah lingkungan, menggunakan media/alat bantu, atau dapat juga mengadakan kegiatan di luar kelas. Komponen efektivitas merupakan kesesuaian antara pelaksanaan tugas dengan sasaran yang dituju. Artinya, apa saja yang digariskan dalam kegiatan pembelajaran terpenuhi semua dengan tepat waktu artinya berlangsungnya pembelajaran yang tuntas, kesesuaian dengan apa yang direncanakan dengan apa yang diwujudkan. Seluruh komponen tersebut tidak dapat dipisahkan antara satu dan lainnya, dan merupakan suatu komponen yang utuh dalam mewujudkan teacher-preneur. Berikut gambar pengembangan model teacherpreneur. Berikut ini disajikan model teacherpreneur sebagaimana pada Gambar 3.

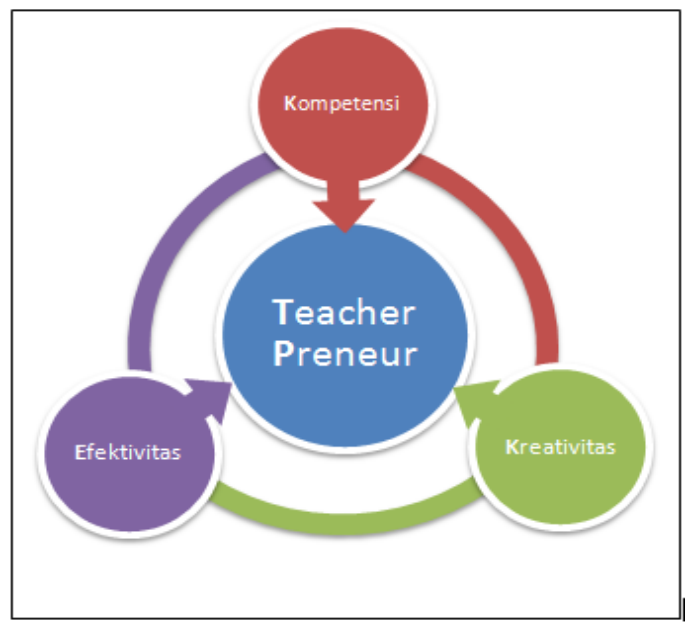

Gambar 3. Model Akhir Teacherpreneur

Komponen kompetensi teacherpreneur produk akhir mencakup komponen: (1) kompetensi pedagogik, yaitu kemampuan mengelola pembelajaran peserta didik yang meliputi pemahaman terhadap peserta didik, perancangan dan pelaksanaan pembelajaran, eva- luasi hasil belajar dan pengembangan peserta didik untuk mengaktualisasikan berbagai potensi yang dimiliki; (2) kompetensi sosial yaitu kemampuan guru sebagai bagian dari masyarakat untuk berkomunikasi dan bergaul secara efektif dengan peserta didik, sesama pendidik, tenaga kependidikan, orang tua/ wali peserta didik, dan masyarakat sekitar; (3) kompetensi kepribadian yaitu kemampuan kepribadian yang mantap, stabil, dewasa, arif, dan berwibawa menjadi teladan bagi peserta didik dan berakhlak mulia; (4) kompetensi profesional yaitu kemampuan penguasaan materi pembelajaran secara luas dan mendalam yang memungkinkan membimbing peserta didik memenuhi standar kompetensi. Berikut ini disajikan gambar produk akhir komponen kompetensi guru model teachepreneur sebagaimana pada Gambar 4.

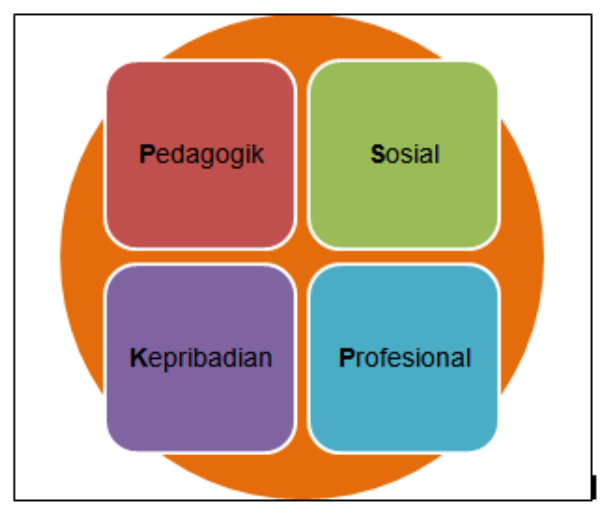

Gambar 4. Komponen Kompetensi Model Akhir Teacherpreneur

Komponen kreativitas model teacherpreneur terdiri dari komponen: (1) Berpikir kreatif yaitu keadaan seseorang yang dapat menemukan hal-hal yang baru atau mengembangkan suatu keadaan dalam pencapaian tujuan. Berpikir kreatif merupakan sikap yang telah dijelaskan oleh Piirto (2011) terdiri dari aspek persiapan, inkubasi, kombinasi, verifikasi, dan aplikasi; (2) Bersikap kreatif adalah keadaan terbuka terhadap pengalaman baru yang luar biasa, luwes dalam berpikir dan bertindak, bebas dalam mengekspresikan diri, dapat mengapresiasi fantasi, berminat pada kegiatan-kegiatan kreatif, dan percaya pada gagasan sendiri (3) Berperilaku kreatif yaitu perilaku keadaan berani dalam pendirian, mandiri dalam berpikir, mampu bekerja keras dan ulet. Berikut gambar skema komponen kreativitas model teacherpreneurhasil revisi yang terdapat pada Gambar 5. 


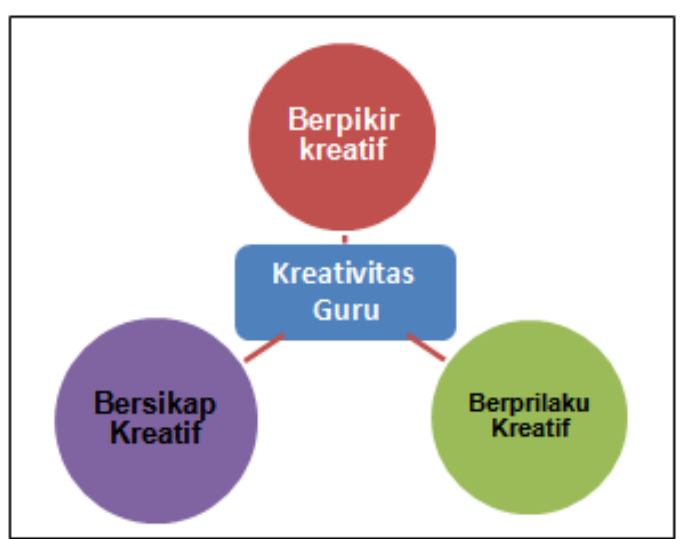

Gambar 5. Komponen Kreativitas Model Akhir Teacherpreneur

Komponen efektivitas model teacherpreneur terdiri dari aspek: (1) keprofesionalan dalam proses mengajar yang lebih reflektif dan keberlanjutan dalam pengembangan kemampuan profesional dirinya; (2) hubungan sosial guru meliputi mengembangkan hubungan sosial yang baik dengan siswa agar termotivasi dan percaya diri selama proses pembelajaran; (3) keberhasilan kelas yaitu kemampuan guru dalam mengelola kelas, melakukan kerjasama dengan orang tua, kolega, dan kemauan untuk selalu meningkatkan keprofesionalannya. Berikut ini disajikan gambar akhir komponen efekifvitas model teachepreneur sebagaimana pada Gambar 6 .

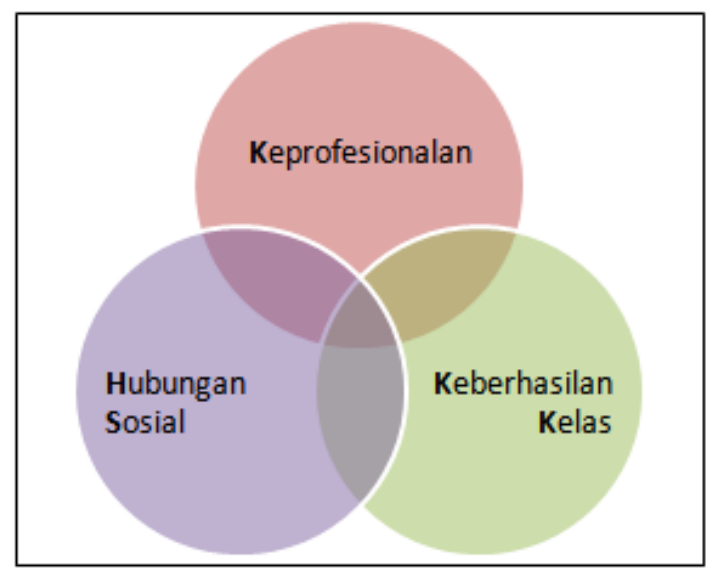

Gambar 6. .Komponen Efektivitas Model Akhir Teacherpreneur

Selain model teacherpreneur yang terdiri dari komponen kompetensi, kreativitas, dan efektivitas juga dirancang desain alur dalam pelaksanaan pelatihan teacherpreneur, tempat pelatihan teacherpreneur yang merupakan bentuk pengembangan guru secara berkelanjutan yang bekerja sama dengan
Dinas Pendidikan dan VEDC Malang (lembaga yang dibentuk oleh pemerintah khusus mengembangkan guru produktif) sebagai bentuk peningkatan profesionalitas guru kejuruan. Berikut ini disajikan gambar alur dalam kegiatan pelatihan teachepreneur sebagaimana pada Gambar 7.

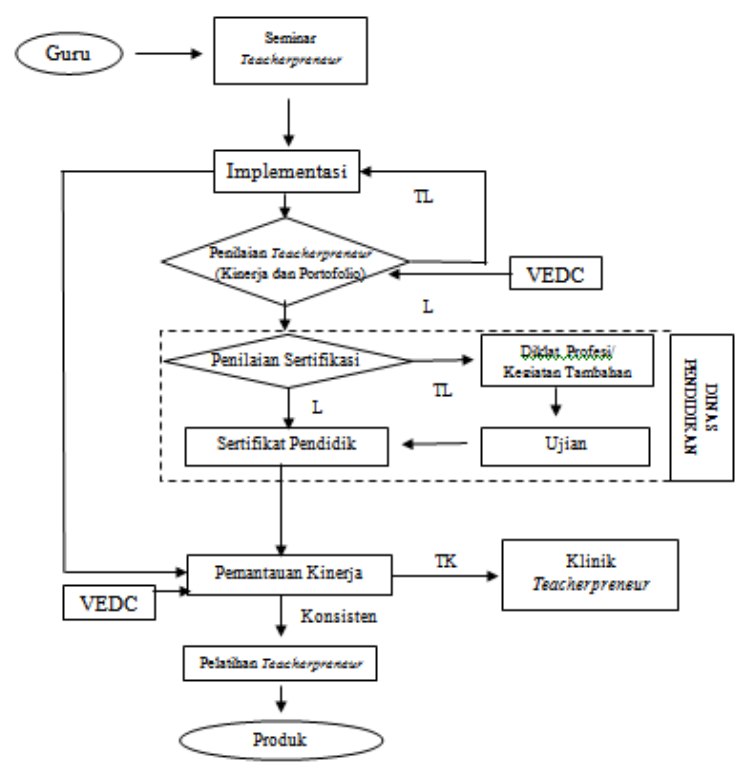

Gambar 7. Desain Alur Pelatihan Teacherpreneur

Pada Gambar 7 dapat dijelaskan bahwa implementasi model teacherpreneur dilakukan dengan diawali memberikan seminar teacherpreneur kepada guru-guru di SMK, menjelaskan pengertian, pentingnya teacherpreneur, sikap teacherpreneur, kriteria seorang teacherprneur. Setelah diberi pembekalan guru-guru tersebut dilihat implementasi/kinerja dan dinilai dengan berbagai indikator yang telah disiapkan oleh panitia dapat berupa portofolio. Dalam tahapan ini dinilai apakah guru tersebut telah memiliki kinerja atau rekam jejak yang baik dengan dibantu data dari Dinas Pendidikan yang setiap tahunnya mengadakan evaluasi kinerja guru. Apabila kinerja dari guru masih memiliki kendala atau belum memenuhi dari yang diharapkan maka terdapat klinik teacherpreneur sebagai bentuk pengembangan diri guru tersebut, sehingga diharapkan akan berdampak peningkatan sikap. Selain itu, bagi guru yang telah memenuhi standar yang diharapkan terdapat pelatihan teacherpreneur dimana pelatihan ini akan diajarkan keterampilan-keterampilan berkaitan peluang dan perkembangan teknologi dalam bidang keilmuan. 


\section{SIMPULAN DAN SARAN}

\section{Simpulan}

Berdasarkan hasil penelitian pengembangan model teacherpreneur pada SMK dapat disimpulkan sebagai berikut:

Pertama, pengembangan pendidik pada SMK bidang keahlian Teknologi dan Rekayasa yang selama ini berjalan terdiri dari program pemerintah dan program sekolah. Program pemerintah terdiri dari kegiatan kemitraan guru SMK, MGMP, OJT, sosialisasi Kurikulum 2013, Ujian kompetensi bagi guru (UKG), diklat assesor, dan pelatihan penulisan karya ilmiah. Program sekolah tergantung berdasarkan kebutuhan sekolah dan strategi yang dilakukan oleh masingmasing kepala sekolah/pimpinan. Salah satu contoh yang telah dilakukan adalah dengan adanya team teaching, shortcourse, dan training motivasi.

Kedua, implementasi program pengembangan profesi pendidik terdapat beberapa kelemahan dan keunggulan. Kelemahan pengembangan profesi pendidik yaitu: (1) Pembagian waktu antara jam mengajar dan jam kegiatan pengembangan (MGMP); (2) belum terdapat evaluasi kemampuan/kompetensi guru terkait setelah pelaksanaan kegiatan pengembangan; (3) faktor anggaran merupakan permasalahan yang paling dominan dalam pengembangan pendidik terutama pada sekolah swasta; (4) perbedaan iklim kerja dan lingkungan antara sekolah swasta dan sekolah negeri; (5) efektivitas pembinaan terhadap kemampuan profesional guru SMK yang diterapkan selama ini masih lemah, kelemahan dari aspek perencanaan, pelaksanaan, dan pengawasan; (6) pembinaan dalam bentuk diklat dalam jabatan dirasa masih belum maksimal; (7) kurangnya perhatian dari pengelola/pimpinan/kepala sekolah dalam hal pelaksanaan pengembangan bagi pendidik; (8) pengembangan pendidik belum dirasa suatu hal yang penting.

Keunggulan dalam pengembangan pendidik yaitu: (1) terdapat banyak program pengembangan bagi pendidik yang diadakan, dan telah difasilitasi oleh pemerintah melalui Dinas Pendidikan Kota; (2) sebagian besar sekolah telah memiliki kelengkapan fasilitas dan sarana prasarana dalam melaksanakan kegiatan pembelajaran; (3) perkembangan teknologi yang bergitu banyak dan beragam dapat dimanfaatkan untuk mempermudah pelaksanaan kegiatan pembelajaran; (4) kualifikasi guru-guru telah memenuhi standard nasional sebagai pendidik; (5) telah diterapkannya manajemen berbasis sekolah sehingga kepala sekolah dapat leluasa mengembangkan pendidik yang terdapat di sekolah; (6) keterlibatan dan kedekatan dengan LPTK dan perguruan tinggi memudahkan pengembangan pendidik; (7) beberapa SMK telah menjalin kerjasama dengan DU/DI.

Ketiga, grand design hasil pengembangan model teacherpreneur pada SMK terdiri dari: (1) model teacherpreneur terdiri dari komponen penyusun yaitu kompetensi, kreativitas, dan efektivitas. (2) komponen kompetensi teacherpreneur terdiri dari kompetensi pedagogi, kompetensi sosial, kompetensi kepribadian, dan kompetensi profesional, (3) komponen kreativitas teacherpreneur terdiri dari aspek berpikir kreatif, bersikap kreatif, dan berperilaku kreatif, (4) komponen efektivitas terdiri dari keprofesionalan, hubungan sosial, dan keberhasilan kelas.

Keempat, hasil uji internal yang dilakukan dapat disimpulkan bahwa ahli setuju: (1) komponen model telah lengkap (92,83\%); (2) struktur komponen model telah jelas $(91,65 \%)$; (3) hubungan antarkomponen model telah jelas $(95,83 \%)$; (4) model memiliki keterbacaan yang baik $(95,83 \%)$; (5) model telah layak $(95,83 \%)$; dan (6) model efektif jika diimplementasikan $(87,5 \%)$.

\section{Saran}

Produk pengembangan disarankan untuk dimanfaatkan dalam hal sebagai berikut.

Pertama, model pengembangan teacherpreneur dapat dimanfaatkan dalam meningkatkan profesionalitas guru sehingga dapat mewujudkan SMK yang tangguh dan berdampak pada peningkatan SDM yang dihasilkan. Kedua, Pengembangan model teacher-preneur perlu didukung dengan berbagai pihak yaitu Dinas Pendidikan, Kepala Sekolah, LPTK dan guru SMK untuk mengetahui kelemahan atau kekurangan yang masih terdapat dalam model. Ketiga, Pengembangan model teacher-preneur dirancang dapat diterapkan di SMK swasta dan negeri, dan dari berbagai jurusan. Keempat, Pengembangan model teacherpreneur dirancang dapat diman- 
faatkan oleh LPTK sebagai salah satu model pelatihan guna meningkatkan profesionalisme guru pada SMK.

\section{DAFTAR PUSTAKA}

Borg, W. R.; and Gall, M, D. (1983). Educational Research: An Introduction. New York and London : Longman.

Dharma, Surya. (November 2012). PTK Dikmen. Media Informasi dan Komunikasi PTK Pendidikan Menengah. Jakarta. Direktorat Pembinaan PTK Dikmen.

Dharma, Surya. (Juli 2012). PTK Dikmen Media Informasi dan Komunikasi PTK Pendidikan Menengah. Jakarta. Direktorat Pembinaan PTK Dikmen.

Jalmo, Tri \& Rustaman, Nuryani Y. (2010). Pengembangan Program Pelatihan Peningkatan Kompetensi Guru IPA.
Forum Kependidikan, Volume 30, Nomor 1 Juni 2010. halaman 79 - 86.

Milles, M.B \& A.M. Huberman. (1994). Qualitative data analysis. California: SAGE Publications Inc.

Novan, A.W. (2012). Teacherpreneurship. Yogyakarta: AR-RUZZMEDIA.

Republik Indonesia. (2005). Undang-Undang RI Nomor 14, Tentang Guru dan Dosen.

Republik Indonesia. (2003). Undang-undang RI Nomor 20 pasal 40 ayat $1 \mathrm{c}$, tentang pembinaan karir bagi pendidik dan tenaga kependidikan.

Salim, Sardi. (2009). Upaya peningkatan kompetensi profesional guru sekolah kejuruan. 